\title{
$\begin{array}{lllllllllllllllll}\mathbf{R} & \mathbf{O} & \mathbf{Z} & \mathbf{P} & \mathbf{R} & \mathbf{A} & \mathbf{W} & \mathbf{Y} & \mathbf{I} & \mathbf{A} & \mathbf{R} & \mathbf{T} & \mathbf{Y} & \mathbf{K} & \mathbf{U} & \mathbf{L} & \mathbf{Y}\end{array}$
}

Saeculum Christianum

t. XXIV (2017), s. 5-16

\author{
KS. TADEUSZ KOŁOSOWSKI SDB \\ WNHiS UKSW, Warszawa
}

\section{TROSKA O CHORYCH W KLASZTORACH STAROŻYTNYCH W ŚWIETLE WYBRANYCH REGUL MONASTYCZNYCH}

\section{Wprowadzenie}

Pierwszą formą życia monastycznego, która powstała na przełomie III i IV w., był anachoretyzm. Polegał on na tym, że mnich-pustelnik udawał się do jakiegoś odludnego miejsca, najczęściej na pustynię, gdzie zdobywając na pożywienie tylko to, co dała mu natura, oddawał się modlitwie, lekturze Pisma Świętego i praktykom ascetycznym ${ }^{1}$. Nieco później powstały pierwsze zgromadzenia cenobityczne. Cenobityzm różnił się od anachoretyzmu przede wszystkim tym, że mnisi żyli we wspólnocie w zamkniętym klasztorze ${ }^{2}$, a ich życie normowała reguła klasztorna. Taka reguła „określała każdy aspekt życia członka wspólnoty. Jedzenie, praca, modlitwa, strój, odpoczynek wpisane zostały w schematycznie urządzony rytm życia klasztoru”3. P. Aszyk w książce poświęconej etycznym aspektom starożytnej medycyny zauważa: „Wiele starożytnych reguł zakonnych instruowało szczegółowo mnichów o sposobie życia, zasadach funkcjonowania, rygorach ascezy obowiązujących we wspólnotach oddających swe życie Bogu. Mnisi i mniszki poddawali się bardzo surowej dyscyplinie, codzienne obowiązki i umartwienia były precyzyjnie wyszczególnione. Zorganizowana wspólnota zakonna miała być sprawnie zarządzaną strukturą, w dużej mierze samowystarczalną, zagospodarowującą każdą chwilę dnia swych członków od momentu pobudki do zaśnięcia"4.

Celem niniejszego artykułu jest próba odpowiedzi na pytanie, w jaki sposób wschodnie i zachodnie reguły monastyczne normowały w starożytnych klasztorach życie chorych. Czy mieli oni wśród swoich braci lub sióstr jakiś specjalny status? Jakie osoby w klasztorze i w jaki sposób były odpowiedzialne za opiekę i troskę o chorych? Reguły monastyczne są w tym względzie ciekawym i unikatowym źródłem informacji o działaniach podejmowanych

\footnotetext{
Por. J. Dziewulski, Życie codzienne mnicha cenobity w Egipcie na podstawie „Reguly” św. Pachomiusza, „Seminare", 31/2012, s. 243.

2 Por. ibidem.

A. Kowalska, Ciało a struktura społeczna. Przypadek wczesnochrześcijańskiego monastycyzmu egipskiego, „The Polish Journal of the Arts and Culture”, 1/2013, nr 4, s. 41.

4 P. Aszyk, Etyczne oblicza starożytnej medycyny. Wczesne chrześcijaństwo wobec przedchrześcijańskich wzorców moralnych związanych z uprawianiem sztuki leczenia, Warszawa 2010, s. 94.
} 
wobec wymagających opieki chorych członków zakonnej społecznościs. Pod tym kątem przeanalizowano wnikliwie kilka reguł monastycznych. Reguły te powstały w różnych regionach ówczesnego świata: Egipt, Afryka Północna, Galia, Italia i Hiszpania. Powstały one pomiędzy IV a VII w. i dotyczą mnichów i dziewic.

\section{Reguta Pachomiusza}

Powszechnie uważany za ojca cenobityzmu Pachomiusz urodził się około 292 r. w miejscowości Sne w Górnym Egipcie w zamożnej, wiejskiej rodzinie pogańskiej. Stąd zapewne jego znajomość, oprócz greki, języka koptyjskiego. W 3I2 r. uczestniczył jako żołnierz w kampanii Maksymina Daji przeciw Licyniuszowi. Uwięziony jako jeniec w pobliżu Teb zaznał tam życzliwości ze strony chrześcijan. Dzięki ich postawie sam zapragnął zostać chrześcijaninem. Dokonało się to mniej więcej rok później, gdy po uwolnieniu osiadł w wiosce Szeneset. Wkrótce postanowił zostać anachoretą u boku innego pustelnika, Palamona. Po Io latach przeniósł się do miejscowości Tabennisi. Tutaj zgromadziła się wokół niego wspólnota osób pragnących go naśladować. Dlatego około 324 r. zaczął nadawać ramy organizacyjne zgromadzonej wokół niego wspólnocie. W latach 329-340 założył pięć klasztorów, a także przyłączył wspólnoty na ich własną prośbę ${ }^{6}$.

Dla uregulowania życia klasztornego konieczną rzeczą było nadanie odpowiedniej reguły życia. W miarę narastania problemów i trudności życia cenobitycznego, a także zdobytych doświadczeń tworzono przepisy, na początku dość chaotycznie. Stopniowo jednak formowała się Reguta św. Pachomiusza, uzupełniana coraz to nowymi przepisami przez jego następców. $Z$ tej też przyczyny całość tekstu reguły nie posiadała jakiegoś organicznie zwartego i logicznie ułożonego schematu. Miejsce systematyzacji zajęło nastawienie praktyczne. W obecnym stanie badań trudno jest ustalić, które przepisy pochodzą od samego Pachomiusza, a które od jego następców, jak również, kiedy zakończył się proces powstawania tej Reguly. Składa się ona z czterech części: Przykazania (Praecepta), Przykazania i postanowienia (Praecepta et Instituta), Przykazania i orzeczenia (Praecepta atque Iudicia) oraz Przykazania i prawa (Praecepta ac Leges). Najstarsza postać Reguły nie jest znana. Wiadomo tylko, że była zredagowana w języku koptyjskim, z tej racji, że w zasadzie przyjmowano do tej społeczności Koptów. Zawierała ona niewielką ilość przepisów, raczej o charakterze ogólnym, które w miarę potrzeb uzupełniano lub modyfikowano nowymi przepisami. W całości zachowała się tylko w łacińskim przekładzie, dokonanym przez św. Hieronima w 404 r. Dzięki temu przekładowi rozpowszechniła się na Zachodzie. Przyjmuje się, że św. Hieronim zachował dokładnie porządek tekstu, ale nie jest pewne, czy przekład jest dokładny, oraz czy uwzględnia wszystkie przepisy?

Dla chorych w klasztorach pachomiańskich przeznaczone było specjalnie wyznaczone miejsce zwane izbą chorych (locus aegrotantium) ${ }^{8}$. Na określenie izby chorych w Regule

\footnotetext{
Por. ibidem.

6 Por. V. Desperez, Wstęp, w: Pachomiana Latina, red. M. Starowieyski, Kraków 1996, s. 15; J. Dziewulski, op. cit., s. 243-244.

Por. M. Kanior, Historia monastycyzmu chrześcijańskiego, t. 1: Starożytność, Kraków 1993, s. 63-64.

8 Por. Pachomiusz, Reguła, 42, tłum. A. Bober, w: Pachomiana Latina, red. M. Starowieyski, Kraków 1996, s. 136.
} 
występują także terminy: cella languentium ${ }^{9}$, cella aegrotantium ${ }^{\text {IO }}$ i locus infirmorum ${ }^{\text {II }}$. Wśród badaczy (Andrew Crislip) nie brak opinii, że izby chorych były prototypami dla szpitali tworzonych przez Bazylego Wielkiego w latach siedemdziesiątych IV stulecia ${ }^{\mathrm{I}}$. Do dyspozycji chorych była także specjalna jadalnia (triclinium aegrotantium) ${ }^{13}$. Chorzy udawali się do niej pod opieką pielęgniarzy i tam spożywali posiłki ${ }^{14}$. Szczególna troska o chorych należała do przełożonego (praepositus). W posłudze na rzecz chorych wspierali go pielęgniarze (ministri aegrotantium) ${ }^{15}$. W dyspozycji pielęgniarzy było wszystko, co konieczne do opieki nad chorymi. Od nich przełożony odbierał te rzeczy i przydzielał chorym ${ }^{16}$. Jeżeli któryś z pielęgniarzy zachorował, opiekę nad nim przejmowali inni pielęgniarze i przełożony domu ${ }^{17}$. Do przełożonego domu należało także udzielanie pozwolenia na odwiedziny krewnych chorych braci ${ }^{18}$. Bracia słabi i chorzy podczas podróży pozostawali pod opieką tygodniowych dyżurnych (hebdomadarii) ${ }^{19}$.

Wśród podawanych w klasztorze produktów żywnościowych były takie, które wyłącznie były podawane chorym. Według reguły były to wino (vinum) i zupa [rybna] (liquamen ${ }^{20}$. Zupę mógł spożywać także brat, który zachorował, a przebywał wraz z braćmi poza klasztorem ${ }^{21}$. Wszelka żywność, którą dostarczali do klasztoru krewni braci w większości przeznaczana była także dla chorych ${ }^{22}$.

Mnichów często postrzegano jako brudnych i niechlujnych. Nie troszczyli się oni o swój wygląd zewnętrzny. Wynikało to z deprecjacji ciała, które postrzegali jako źródło pokus. Stąd nie myli się i nie nacierali ciała oliwą, nie chcąc, aby dbałość o ciało nie przysłoniła potrzeb ducha ${ }^{23}$. Reguła pachomiańska nakazywała po dniu pracy obmycie i namaszczenie rąk. Nie pozwalano myć i namaszczać całego ciała, z jednym tylko wyjątkiem, mianowicie $\mathrm{w}$ przypadku widocznej choroby ${ }^{24}$. Braciom chorym oraz w podeszłym wieku pozwalano także na spoczynek w zamkniętej celi ${ }^{25}$.

\section{Augustyn, Regula}

Augustyn zapoznał się z ruchem monastycznym jeszcze przed swoim nawróceniem, podczas pobytu w Italii. Kiedy przebywał w Mediolanie, Augustyn zetknął się ze św. Ambrożym,

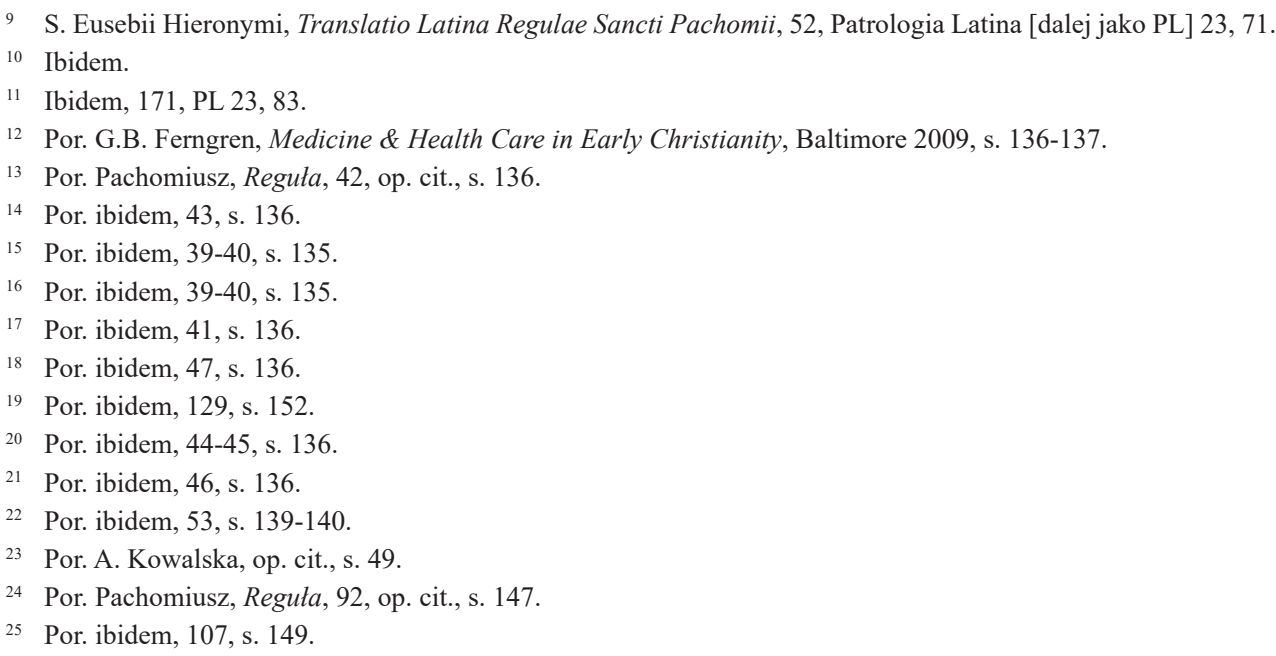


który sam próbował organizować tam życie zakonne. Być może Augustyn wiedział o próbach organizacji życia cenobitycznego dokonywanych przez Euzebiusza, biskupa Vercellae. Duże wrażenie, co miało istotny wpływ na ostateczny akt nawrócenia, wywarło na Augustynie opowiadanie Pontycjana o życiu św. Antoniego Pustelnika i o mnichach żyjących w Mediolanie oraz Trewirze. Wycofanie się z przyjaciółmi do miejscowości Cassiciacum i pobyt tam uznaje się niejako za pierwszy etap życia monastycznego św. Augustyna. Po przyjęciu chrztu, podczas pobytu w Rzymie Augustyn odwiedza wiele klasztorów męskich i żeńskich oraz studiuje ich sposób życia. Ideały monastyczne realizuje Augustyn w swoim życiu po powrocie do Afryki. Pierwszą wspólnotę organizuje on w rodzinnej Tagaście. Po przeniesieniu się do Hippony, gdzie otrzymuje święcenia kapłańskie, organizuje w tym mieście klasztor, głównie dla ludzi świeckich, choć nie wykluczał z niego kapłanów ${ }^{26}$.

Za podstawowe dla Reguły św. Augustyna uznaje się trzy utwory: Porzadek klasztoru (Ordo monasterii), Reguła dla mnichów (Praeceptum) oraz List 2II, w którym znajduje się Obiurgatio, czyli napomnienie skierowane do kłócących się mniszek oraz Regularis informatio - żeński wariant reguły określanej wyżej jako Praeceptum ${ }^{27}$. Wzmianki na temat chorych znajdujemy tylko w Praeceptum.

W świetle Praeceptum troska o słabych, chorych, jak i tych, którzy po chorobie powracali do zdrowia, była powierzona jednej osobie. Augustyn nie określa jednak dokładniej, kim była ta osoba i jakie funkcje we wspólnocie sprawowała. Zadaniem tej osoby było również zaopatrywanie chorych braci w żywność ${ }^{28}$. Chorzy mogli również jeść poza porami wyznaczonymi na posiłki ${ }^{29}$. Augustyn wskazuje także na konieczność konsultacji z lekarzem, jeśli ktoś cierpi na ukrytą chorobę ${ }^{30}$. Augustyn zwraca jednak braciom uwagę, aby po wyzdrowieniu nie mieli już upodobania w wygodach, które krzepiły ich jako chorych ${ }^{31}$. Jak wskazuje na to Praeceptum, Augustyn bardzo dobrze troszczył się o higienę przebywających w klasztorze braci. Mycie całego ciała było czymś bardzo ważnym, a już szczególnie w przypadku chorych, zwłaszcza gdy lekarz radził im mycie się: „Mycia ciała, szczególnie zaś, gdy zachodzi konieczność ze względu na chorobę, nie należy bynajmniej zakazywać; trzeba je myć bez szemrania z porady lekarza, do tego stopnia, że nawet jeśli ktoś nie chce, powinien uczynić z nakazu przełożonego to, co jest potrzebne dla zdrowia. Jeśliby zaś tego chciał, a być może nie ma takiej potrzeby, niech nie słucha swych pragnień. Czasami bowiem uważa się za pożyteczne to, co jest przyjemne, choć przynosi szkodę"ß2.

\footnotetext{
${ }^{26}$ Por. M. Starowieyski, Wprowadzenie [do Reguły św. Augustyna], w: Starożytne reguły zakonne, red. E. Stanula, Warszawa 1970, s. 73-75.

27 Por. P. Nehring, Prawodawstwo monastyczne św. Augustyna, w: Zachodnie reguly monastyczne, red. M. Starowieyski, Kraków 2013, s. 228; G. Lawless, Przegląd monastycyzmu augustiańskiego i kilka sugestii co do dalszych badań, w: Duchowość starożytnego monastycyzmu. Materiały z Międzynarodowej Sesji Naukowej, Kraków-Tyniec, 16-19 listopada 1994, red. M. Starowieyski, Kraków 1995, s. 67-68.

28 Por. Augustyn, Reguła (Praeceptum), V, 8, tłum. M. Starowieyski, P. Nehring, w: Zachodnie reguly monastyczne, op. cit., s. 273.

29 Por. ibidem, III, 1, s. 266.

30 Por. ibidem, V, 6, s. 273.

31 Por. ibidem, III, 5, s. 267.

32 Ibidem, V, 5, s. 273: "Lavacrum etiam corpori, cum infirmitatis necessitas cogit, minime denegetur Fiat sine murmure de consilio medici, ita ut etiam si nolit, jubente praeposito faciat quod faciendum est pro salute. Si autem velit, et forte non expedit, suae cupiditati non obediatur: aliquando enim etiam si noceat, prodesse tamen creditur quod delectat.” Tekst łaciński: Augustinus, Regula, PL 32, 1379-1380.
} 


\section{Reguły Cezarego z Arles}

Cezary urodził się w 470 r. w miasteczku Cabillonum. Około 20. roku życia wstąpił do opactwa w Lerynie. Po kilku latach został celem poprawy nadszarpniętego przez praktyki ascetyczne zdrowia, odesłany przez opata do Arles. W tym też czasie biskup tego miasta Eoniusz włączył go do grona swoich duchownych. Cezary został najpierw diakonem, a następnie kapłanem. W 499 r. biskup mianował go opatem w jednym z klasztorów na przedmieściach Arles. W trzy lata później na żądanie Eoniusza został jego następcą, biskupem w Arles i rozpoczął blisko czterdziestoletni okres duszpasterskiej działalności. Głosił kazania w miastach i parafiach wiejskich oraz wizytował podległe mu ośrodki życia kościelnego. Jako biskup, a od 6 listopada 5I3 r. na mocy decyzji papieża Symmacha metropolita i Wikariusz Stolicy Apostolskiej oraz Prymas Galii i Hiszpanii, organizował życie chrześcijańskie na podległym mu terenie. W celu tworzenia coraz lepszych zewnętrznych warunków dla rozwoju życia kościelnego zwołał i przewodniczył kilku synodom, na których podjęto ważne decyzje o charakterze organizacyjnym i dyscyplinarnym. Cezary wykazywał się także znaczącą działalnością polityczno-społeczną. Wykorzystując swój moralny autorytet przyczyniał się do uwolnienia mieszkańców podbitych miast, wykupywał z własnych dóbr niewolników, rozwijał na szeroką skalę konieczną wówczas działalność charytatywną. Organizował także na podległym terenie życie monastyczne poprzez budowę klasztorów i pisanie dla nich reguł. Zmarł 27 sierpnia 542 r. ${ }^{33}$.

Na literacką spuściznę monastyczną Cezarego z Arles składają się: Mowy do mnichów (Sermones 233-238), List do mniszek, Reguła dla dziewic oraz Reguła dla mnichów. Posiadamy sześć tzw. mów św. Cezarego z Arles skierowanych do mnichów, przy czym jedna z nich, mowa 233, jest rozprawą pisemną, która w dawnych opracowaniach z zasady była nazywana listem. Wydaje się, że pięć mów było adresowanych do wspólnoty klasztornej w okolicach Arles, gdzie uprzednio Cezary był opatem, zaś mowa 236 została wygłoszona w Lerynie. Natomiast mowa 238, nieco odmienna od pozostałych, jest pouczeniem okazjonalnym, podającym, jak przeżywać Wielki Post. Datacja mów jest trudna do ustalenia, wydaje się, że pochodzą one z okresu po 503 r., kiedy to Cezary był już biskupem Arles ${ }^{34}$. List do mniszek jest pierwszym z żeńskich tekstów monastycznych naszego autora i poprzednikiem Reguły dla mniszek. Najważniejszym tematem Listu jest czystość, centralna cnota monastycyzmu żeńskiego ${ }^{35}$. Reguła dla dziewic jest najważniejszym dziełem ascetycznym św. Cezarego, przede wszystkim dlatego, że jest to pierwsze (nie licząc żeńskiej wersji Reguły Augustyna) tego typu pismo napisane specjalnie dla kobiet ${ }^{36}$. Wreszcie Regułę dla mnichów Cezary zredagował w nie znanych nam bliżej okolicznościach. Była ona dawniej uważana przez badaczy za wcześniejszą niż Reguła dla dziewic, ale Adalbert de Vogüé wykazał, że jest odwrotnie. Reguła dla mnichów została napisana pomiędzy rokiem 534 a 542. Jest ona jakby nową wersją reguły żeńskiej skierowaną do mężczyzn. Została napisana bez ściśle określonego adresata,

\footnotetext{
33 Por. T. Kołosowski, Kult chrześcijański w nauczaniu i działalności biskupa Cezarego z Arles, „Seminare”, 15/1999, s. 305-306; tenże, Działalność polityczno-społeczna biskupa Cezarego z Arles, „Saeculum Christianum”, 1/1994, s. 55-64.

34 Por. J. Piłat, Wstęp, w: Cezary z Arles, Pisma monastyczne, red. M. Starowieyski, Kraków 1994, s. 17.

35 Por. ibidem, s. 20.

36 Por. ibidem, s. 23.
} 
stąd jej ton jest dość neutralny w porównaniu z Regułą dla dziewic. Reguła dla mnichów jest syntezą i sumą nauki monastycznej Cezarego z Arles ${ }^{37}$.

Reguła dla dziewic bardzo mocno podkreśla obowiązek troski o chore siostry. Chore albo dotknięte jakąkolwiek słabością siostry miały przydzieloną specjalną opiekunkę. Cezary zaznacza, że powinna to być siostra pełna wierności, skruchy i wrażliwa na potrzeby chorych sióstr. W przypadku potrzeb dotyczących szczególnego żywienia opiekunka chorych powinna zwracać się do siostry szafarki, która zajmowała się spiżarnią (cellaria). Cezary zaznacza nawet, że jeśliby wymagała tego potrzeba chorych, matka klasztoru (mater monasterii) może dla chorych sióstr wyznaczyć osobną wspólną spiżarnię i kuchnię ${ }^{38}$. Chore siostry miały także wspólne specjalne pomieszczenie, w którym zamieszkiwały podczas choroby ${ }^{39}$. Zarówno opiekunka jak i szafarka opiekę nad chorymi siostrami mają traktować jako zadanie priorytetowe: „Co zaś do szafarki i tej, która ma usługiwać chorym, należy im nakazać uroczyście przed Bogiem i aniołami Jego, aby troskę o chore stawiały ponad każdą inną"40.

Chore siostry zwalniano z postu. Reguła zastrzega jednak, że dotyczy to tylko czasu choroby. „Kiedy [chore] odzyskają dawne siły, niech powrócą do zwykłego postu, w którym jest więcej szczęścia"4I. Jadłospis chorych wzbogacano także o produkty, których nie wolno było spożywać innym siostrom. W takim przypadku polecenie do spożywania mięsa wydawała ksieni (abbatissa) ${ }^{42}$. Cezary, pisząc Regułę, był świadomy sytuacji, że chore bądź słabe siostry z poczucia wstydu mogą nie chcieć prosić o wyjątek, stąd zwraca się do chorych i ich opiekunek w następujących słowach: „I jeśli one ze wstydu nie ośmielają się prosić o wyjątek, to wy każecie szafarkom, aby im mięso dawały, a im samym nakażcie przyjmować. I niech uwierzą mocno, że cokolwiek o jakiejkolwiek porze otrzymują za pozwoleniem lub z rozkazu starszej, Chrystusa przyjmują w tym posiłku’ł3. W klasztorze znajdowało się również wino, które mogły otrzymywać chore siostry oraz te, które delikatniej wychowano ${ }^{44}$. Chore siostry za poradą lekarską miały także obowiązek korzystania z łaźni. Ten obowiązek Cezary wyraża następująco: „Toteż nawet jeśli chora sama nie chce użyć łaźni, niech na rozkaz przełożonej zrobi to, czego potrzeba jej dla zdrowia ${ }^{45}$. Jednak korzystanie z łaźni poza przypadkiem choroby uznawano za kaprys" ${ }^{\text {"46 }}$.

\footnotetext{
37 Por. ibidem, s. 27-28.

38 Por. Cezary z Arles, Reguła dla dziewic, [30] 32, tłum. M. Borkowska, w: Zachodnie reguły monastyczne, op. cit., s. 419.

39 Por. ibidem, [7] 9, s. 411.

40 Ibidem, [39] 42, s. 424. „Cellaria vero, et illa quae infirmis servitura est, super omnem sollicitudinem cura illis et diligentia infirmarum coram Deo et angelis ejus denuntietur. Tekst łaciński: Caesarius Arelatensis, Regula ad virgines", PL 67, 1115.

${ }^{41}$ Cezary z Arles, Reguła dla dziewic, [20] 22, op. cit., s. 415. ,[...] sed cum vires pristinas reparaverint, redeant ad feliciorem abstinentiae consuetudinem.” Tekst łaciński: Caesarius Arelatensis, Regula ad virgines, PL 67, 1110.

42 Por. Cezary z Arles, Reguła dla dziewic, 71, op. cit., s. 441-442.

43 Ibidem, [39] 42, s. 424. ,[...] si illae propter verecundiam petere non praesumunt, vos eis jubeatis a cellariis dari, et ipsis ut accipiant ordinetis. Et certissime confidant, quidquid dispensante aut jubente seniore qualibet hora percipient, in illa repausatione Christum accipient.” Tekst łaciński: Caesarius Arelatensis, Regula ad virgines, PL 67, 1115.

44 Por. Cezary z Arles, Reguła dla dziewic, [28] 30, op. cit. s. 419.

45 Ibidem [29] 31, s. 419. ,[...] ita ut etsi lavare nollet illa quae infirma est, jubente seniore fiat quod opus fuerit pro salute." Tekst łaciński: Caesarius Arelatensis, Regula ad virgines, PL 67, 1112.

46 Por. Cezary z Arles, Reguła dla dziewic, [29] 31, op. cit, s. 419.
} 
Zważywszy na obszerne potraktowanie kwestii chorych w Regula ad virgines potraktowanie tego tematu w Regula ad monachos budzi pewien niedosyt. Mamy w niej bowiem na ten temat tylko jedno zdanie: „Chorymi należy tak się opiekować, aby jak najszybciej wyzdrowieli'"47.

\section{Leander z Sewilli, O pouczeniu dziewic i pogardzie świata}

Leander urodził się około 540 r. prawdopodobnie w Kartaginie z ojca Seweriana, pochodzenia iberorzymskiego, i matki Wizygotki. Miał troje młodszego rodzeństwa, braci Fulgencjusza i Izydora oraz siostrę Florentynę. Później rodzina przeniosła się do Betyki (Andaluzja), a następnie do Sewilli. W tym mieście matka przyjęła katolicyzm, a Leander wstąpił do klasztoru, gdzie otrzymał dobrą formację duchową. Około 577 r. został on arcybiskupem Sewilli i na tym urzędzie odegrał ważną rolę w sprawach politycznych. Całe życie poświęcił umocnieniu katolicyzmu w Hiszpanii. Umarł około 600 r. i jego następcą na stolicy biskupiej w Sewilli został jego brat Izydor ${ }^{48}$.

Dzieło De institutione virginum et de contemptu mundi napisał Leander w pierwszych latach biskupstwa, w okresie zagrożenia katolicyzmu. Nie jest to reguła zakonna w ścisłym znaczeniu, gdyż nie ma charakteru prawnego. Jest to raczej zachęta skierowana do siostry Florentyny, która dopiero co wstąpiła do klasztoru. Leander ukazuje jej wielkość i piękno dziewictwa. Oblubieńcem dla dziewic jest sam Jezus Chrystus, a ich patronką jest Jego Matka. Pouczenie to ma charakter bardzo osobisty, jest pełne osobistego zaangażowania i elementów autobiograficznych. Natomiast część druga, zawierająca 3I wskazań ascetycznych, omawia sposób postępowania dziewic i ideał ascetyczny mniszki ${ }^{49}$.

O tym, że dzieło Leandra jest raczej traktatem na temat dziewictwa niż regułą monastyczną świadczy także potraktowanie w tym dziele kwestii chorych sióstr. Słowa Leandra mają tutaj jakby charakter porady, jak jego siostra Florentyna powinna odnosić się do chorych sióstr albo jak postępować w przypadku własnej choroby. Wobec chorych sióstr powinna występować z troskliwą i uprzejmą posługą. Powinna ona uważać słabości i choroby sióstr za swoje własne. Służyć im nie tylko w zaspakajaniu ich potrzeb cielesnych podczas choroby, ale również udzielać im wsparcia duchowego ${ }^{50}$. Chorym siostrom Leander zaleca picie wina. Powinny je one pić jednak jako lekarstwo i jako takiego nie nadużywać. Natomiast dziewica ciesząca się dobrym zdrowiem powinna całkowicie wystrzegać się wina ${ }^{51}$. Natomiast co do spożywania mięsa przez chore siostry stanowisko Leandra jest nieco bardziej wstrzemięźliwe. Zwraca się osobiście do Florentyny, że ze względu na jej słabe zdrowie nie ośmiela się ani zabraniać jej spożywania pokarmów mięsnych, ani na to pozwalać. Z pewnością powinna się od nich powstrzymać taka dziewica, której na to pozwala stan zdrowia. Przestrzegając dalej o niebezpieczeństwach, jakie wynikają z nadmiernego spożywania mięsa, ostatecznie

\footnotetext{
47 Cezary z Arles, Reguła dla mnichów, 17, thum. M. Borkowska, w: Zachodnie reguły monastyczne, op. cit., 2013, s. 455. „Infirmi tractentur, ut citius convalescant.” Tekst łaciński: Caesarius Arelatensis, Regula ad monachos, 17, PL 67, 1101. op. cit.,

48 Por. M. Kanior, op. cit., s. 225-226.

49 Por. ibidem, s. 226.

50 Por. Leander, O pouczeniu dziewic i o pogardzie świata, 4, tłum. I Gano, w: Zachodnie reguly monastyczne, op. cit., s. 948-949.

51 Por. ibidem, 19, s. 962-964.
} 
apeluje o zachowanie umiaru w tym zakresie ${ }^{52}$. Również kąpieli każda dziewica powinna zażywać wyłącznie ze względów zdrowotnych. Powodem częstych kąpieli powinna być jedynie konieczność wynikająca z choroby. Staranie o ciało, płynące ze zmysłowości, należy uważać za występne ${ }^{53}$.

\section{Izydor z Sewilli, Księga reguły klasztornej}

Wiadomości o życiu Izydora czerpiemy przede wszystkim z Wykazu ksiąg świętego Izydora Brauliona z Saragossy, zawierającego skąpe wzmianki o jego życiu, dokładny spis i opis jego dzieł, a także pochwałę Izydora, stanowiącą cenne świadectwo tego, jak postrzegali Izydora - pasterza i uczonego - jemu współcześni. Inne źródła to opis śmierci Izydora sporządzony przez nieznanego skądinąd diakona Redemptusa, a także życiorys biskupa Sewilli zamieszczony w traktacie O pismach sławnych mężów Ildefonsa z Toledo. Większość uczonych przyjmuje obecnie jako datę jego urodzenia rok 560. Dzieciństwo i młodość Izydora upłynęły w cieniu wielkiego brata Leandra. Można przypuszczać, że były to lata spędzone na nauce, na lekturze Pisma Świętego oraz dzieł licznych pisarzy chrześcijańskich i pogańskich. Świadczą o tym bowiem ,uczone” pisma Izydora. Po śmierci Leandra około roku 600 Izydor został biskupem Sewilli. Jako biskup Izydor przewodniczył ważnym synodom kościelnym. Przyczynił się także do zredagowania Isidoriana, najstarszej wersji pierwszej kanonicznej kolekcji Zachodu, tak zwanej Hispana, w której znalazło się I05 dekretów papieskich oraz akta 67 wschodnich, afrykańskich, galijskich i hiszpańskich synodów. Jest również bardzo prawdopodobne, że uczestniczył on także w redagowaniu łacińskiego przekładu Biblii Vetus Latina Hispana. Troszczył się o rozwój życia monastycznego i szkolnictwo. Wspierał ubogich, a przeczuwając nadejście śmierci, rozdawał jałmużnę jeszcze hojniej, niż czynił to zazwyczaj. Gorliwie i z mocą głosił Słowo Boże, był wspaniałym kaznodzieją. Braulion wspomina o tym, że był wykształcony w każdym rodzaju wymowy, a Ildefons poświadcza, że piękno kazań Izydora tak bardzo oczarowywało słuchających, iż popadali w swego rodzaju osłupienie, tak że po jednym wysłuchaniu nie mogli przypomnieć sobie, o czym właściwie była mowa. Dzięki nadzwyczajnej sile i bogactwu swej osobowości Izydor sprawował pieczę nad państwem Wizygotów, będąc doradcą kolejnych królów wizygockich. Zmarł 4 kwietnia w roku $636^{54}$.

Izydor problematyką zakonną zajmował się w wielu swoich pismach. Jednak szczególny wyraz jego zainteresowanie życiem zakonnym znalazło w regule, którą napisał, wzorując się na pismach Augustyna, Jana Kasjana, Hieronima, Benedykta oraz odwołując się do własnego doświadczenia. Księgę reguły klasztornej Izydor skierował do mnichów z klasztoru honoriańskiego, o którym możemy przypuszczać tylko tyle, że znajdował się niedaleko Sewilli. Jednak w następnych wiekach pismo to było znane i wykorzystywane przez liczne wspólnoty monastyczne w Hiszpanii i poza jej granicami. Podobnie jak inne ówczesne reguły dzieło Izydora stanowi nie tyle kodeks, co raczej eklektyczny zbiór rad, pomocnych dla wspólnoty i jej przełożonych. Regułę Izydora cechuje umiarkowanie i pełne roztropności dostosowanie do ludzkich słabości. Biskup Sewilli pamięta o tym, że większość mnichów wywodziła

\footnotetext{
52 Por. ibidem, 24, s. 970-972.

53 Por. ibidem, 20, s. 964-965.

54 Por. T. Krynicka, Izydor z Sewilli, Kraków 2007, s. 6-15.
} 
się wówczas z najbiedniejszych, najmniej wykształconych warstw ludności, i dostosowuje sposób wypowiedzi do poziomu swoich odbiorców, pisząc językiem ludowym. Pozwala też mnichom na większą niż w innych klasztorach rację wina, nie wymaga, by zrezygnowali z jedzenia mięsa, a w dniach świątecznych każe zaopatrzyć klasztor w lepsze pożywienie ${ }^{55}$.

Jak wobec powyższego Księga reguły klasztornej rozwiązuje kwestię życia we wspólnocie chorych braci? Poświęca im bowiem sporo miejsca. Za troskę o chorych odpowiedzialny był specjalny opiekun. Oto, w jaki sposób Izydor postrzega osobę takiego opiekuna: „Pieczę nad chorymi należy powierzyć mężowi nieskazitelnemu, prowadzącemu świątobliwe życie, który by opiekował się nimi troskliwie i z wielką gorliwością wykonywał to, czego wymaga ich stan" ${ }^{6}$. Zadaniem opiekuna było przede wszystkim zadbanie o to, aby chorzy bracia otrzymywali delikatniejsze posiłki, dopóki nie powrócą do stanu zdrowia. Samym opiekunom nie wolno korzystać z posiłków przygotowanych dla chorych. Zdrowi bracia nie powinni się także gorszyć, że chorych traktuje się z większą wyrozumiałością57. Po tej uwadze Izydor dodaje następujące słowa: „Nie godzi się, aby ktoś ukrywał rzeczywistą chorobę albo też symulował urojoną. Lecz zdolni do pracy niechaj dzięki czynią Bogu i pracują, ci zaś, którzy tego nie mogą, powinni odczuwać żal z tego powodu i doznawać większej wyrozumiałości”58. Chorzy powinni bez szemrania przyjmować przepisane lekarstwa ze względu na cel, jakim jest przywrócenie zdrowia. Tylko rzeczywiście chorym wolno korzystać z kąpieli dla zdrowia ${ }^{59}$. Jedynie oni mogli również posilać się poza wyznaczonymi w klasztorze porami posiłków ${ }^{60}$. Wreszcie chorzy bracia przebywali w oddzielnych pomieszczeniach (locus aegrotantium), oddalonych od kościoła i od cel innych braci. Izydorowi chodziło w tym wypadku o to, aby nic nie zakłócało spokoju chorych ${ }^{61}$. Za zezwoleniem opata bracia chorzy i w podeszłym wieku mogli mieszkać w oddzielnych celach (cellula separata) ${ }^{62}$.

\section{Regula św. Benedykta}

Źródłem poznania postaci św. Benedykta jest II księga Dialogów św. Grzegorza Wielkiego. Benedykt urodził się około 480 r. w Nursji, w zamożnej rodzinie prowincjonalnej szlachty. Rodzice oprócz syna mieli także córkę Scholastykę. Pierwsze nauki Benedykt pobierał w domu rodzinnym. Po ukończeniu nauki w rodzinnej Nursji, mając około I4 lat, został wysłany na dalsze studia do Rzymu. Podczas studiów zetknął się z relacjami o życiu mnichów egipskich, ale również z manichejczykami. Widząc jednocześnie szerzące się zło, uznał pobyt w spoganiałym mieście za szkodliwy dla siebie i odsunął się od świata. Najpierw przyłączył

\footnotetext{
55 Por. ibidem, s. 32-33.

56 Izydor z Sewilli, Księga reguty klasztornej, 22, tłum. I. Gano, w: Zachodnie reguty monastyczne, op. cit., s. 1025: „Cura infirmorum sanae sanctaeque conversationis viro committenda est, qui pro eis sollicitudinem ferre possit, magnaque cum industria praesto faciat quidquid imbecillitas eorum exposcit. Tekst łaciński: Isidorus, Regula monachorum", PL 83, 891.

57 Izydor z Sewilli, Księga reguty klasztornej, 22, op. cit., s. 1026.

58 Izydor z Sewilli, Księga reguly klasztornej, 22, op. cit., s. 1026. „Nullum oportet vel veram corporis infirmitatem celare, vel falsam praetendere. Sed qui possunt Deo gratias agant, et operentur; qui vero non possunt manifestent suos languores, humaniusque tractentur”. Tekst łaciński: Isidorus, Regula monachorum, PL 83, 891.

59 Por. Izydor z Sewilli, Księga reguty klasztornej, 22, op. cit., s. 1026.

60 Por. ibidem, 9, s. 1009

61 Por. ibidem, 1, s. 994.

62 Por. ibidem, 19, s. 1009.
} 
się do wspólnoty kapłanów żyjących przy kościele św. Piotra w Enfide w Górach Sabińskich. Później przeniósł się w odludną dolinę Subiaco, leżącą około 80 km na wschód od Rzymu. Spotkał tu doświadczonego mnicha Romana z pobliskiego klasztoru. Za jego radą osiadł w skalnej grocie, w pobliżu zrujnowanego pałacu Nerona, nad jeziorem utworzonym przez rzekę Anio i zaczął prowadzić surowy żywot pustelnika, na podobieństwo mnichów wschodnich. Z czasem w okolicy rosła sława pustelnika. Grota przestała być pustelnią, ponieważ liczni kandydaci do życia monastycznego pragnęli poddać się jego kierownictwu. Zrezygnował zatem z życia samotnego i w latach 520-527 zorganizował wspólne życie skupienia i modlitwy w I2 klasztorach, pod zarządem mianowanego w każdym domu opata. Sobie zastrzegł ogólne kierownictwo domów i formowanie nowicjuszy w trzynastym klasztorze. Prawdopodobnie posługiwał się jakąś regułą, adaptowaną do miejscowych warunków. Przypomina ona sposób życia według Reguły św. Pachomiusza. Zazdrość i intrygi jednego z duchownych z sąsiedztwa, usiłującego zdeprawować jego uczniów, skłoniła Benedykta do opuszczenia okolic Subiaco. Z grupą uczniów przeniósł się na Monte Cassino, gdzie na ruinach pogańskiej świątyni Jowisza i Apollina zbudował kościół poświęcony śś. Janowi Chrzcicielowi i Marcinowi. Obok stanął klasztor, w którym Benedykt zorganizował pełne życie wspólnotowe, poświęcone modlitwie, zwłaszcza liturgicznej, ręcznej pracy i lekturze duchowej. Zmarł 2I marca prawdopodobnie $547 \mathrm{r}^{63}$

Reguła św. Benedykta składa się z prologu i 73 rozdziałów, spośród których ostatni stanowi epilog. Benedykt zawarł w niej pełny kodeks życia mniszego i obowiązki mnicha. Reguła posiada bardzo praktyczny charakter i jest przejawem ewolucji duchowości monastycznej w kierunku umysłowości ludzi Zachodu. Ten praktyczny charakter Reguły pozwolił ludziom Zachodu na bezpośrednie jej zastosowanie, bez uprzedniej adaptacji, w przeciwieństwie do reguł śś. Pachomiusza czy Bazylego. Autentyczność Reguły św. Benedykta jest pewna. Napisał ją na Monte Cassino pod koniec swego życia. Nie jest dziełem, które zostało napisane od razu w całości. W miarę nabywanego doświadczenia, precyzji myśli prawodawca nie tylko poprawiał i uzupełniał tekst, ale dodawał całe rozdziały ${ }^{6}$.

W Regule św. Benedykta podstawowa troska o chorych powierzona jest opatowi (abbas). Ma on czuwać przede wszystkim nad tym, aby w żaden sposób nie zaniedbywano chorych ${ }^{65}$. W sposób szczególny chorymi powinni się opiekować szafarz klasztorny (cellararius) ${ }^{66}$ oraz pielęgniarz (servitor) ${ }^{67}$. Powinni oni pilnie i troskliwie spełniać posługę wobec chorych. Św. Benedykt bardzo mocno podkreśla znaczenie troski o chorych: „O chorych należy troszczyć się przede wszystkim i ponad wszystko i służyć im rzeczywiście tak, jak Chrystusowi, bo On sam powiedział: „Byłem chory, a odwiedziliście Mnie” (Mt 25,36) oraz: „Co uczyniliście jednemu z tych braci moich najmniejszych, Mnieście uczynili” (Mt 25,40) ${ }^{68}$. Benedykt apeluje jednak do braci, aby wobec choroby wykazywać się cnotą cierpliwości. Dotyczy to zarówno chorych, jak i troszczących się o nich braci: „Ale i sami chorzy niech pamiętają, że bracia służą im dla chwały Bożej i niech przez nadmierne wymagania nie sprawiają przykrości

${ }^{63}$ Por. M. Kanior, op. cit., s. 172-174.

64 Por. ibidem, s. 175-176.

${ }_{65}$ Por. Benedykt z Nursji, Reguła, 36, tłum. A Świderkówna, Kraków 1994, s. 152 (tekst łaciński i polski).

66 Por. ibidem, 31, s. 141.

67 Por. ibidem, 36, s. 154-155.

68 Ibidem, 36, s. 152: „Infirmorum cura ante omnia et super omnia adhibenda est, ut sicut revera Christo, ita eis serviatur, quia ipse dixit: «Infirmus fui et visitastis me»; et: «Quod fecistis uni de his minimis, mihi fecistis»". 
tym, którzy się nimi opiekują. Takich wymagających chorych należy jednak znosić cierpliwie, ponieważ przez nich zyskuje się obfitszą nagrodę" $"$. Chorzy bracia powinni mieć do dyspozycji specjalnie dla nich wyznaczoną celę ${ }^{70}$. Należy im także udostępnić korzystanie z łaźni: ,ilekroć jest to dla nich wskazane”’1. Zwyczajowo mnisi żyjący według Reguły św. Benedykta nie spożywali mięsa. Chorzy jednak mogli uzyskać pozwolenie na jego spożywanie na czas choroby ${ }^{72}$. Mogło to być nawet mięso zwierząt czworonożnych ${ }^{73}$. Czy chorzy bracia powinni pracować? Benedykt nie dopuszcza, aby wyznaczać im pracę ponad ich siły. Powinni otrzymywać jednak jakieś zajęcie, aby nie groziła im bezczynnośćc ${ }^{4}$.

\section{Wnioski}

Jak wyglądała troska o chorych w klasztorach starożytnych męskich i żeńskich w świetle reguł monastycznych, które poddano analizie? Każda z reguł wyznaczała do opieki nad chorymi specjalną osobę spośród braci lub sióstr. Niektóre reguły nie określały bliżej pełnionej przez tę osobę funkcji w klasztorze ani nie określały bliżej zadań związanych z posługą wśród chorych (Reguła św. Augustyna). Cezary z Arles w Regule dla dziewic podaje cechy, jakimi powinna się odznaczać opiekunka chorych, Izydor z Sewilli ponadto określa obowiązki opiekuna. Bardziej precyzyjnie opiekunów chorych określają Pachomiusz i Benedykt. Pachomiusz ogólną troskę powierza przełożonemu domu (praepositus) oraz pielęgniarzom (ministri aegrotantium). Benedykt podstawową troskę o chorych powierza opatowi (abbas), a na specjalnych opiekunów wyznacza szafarza i pielęgniarza.

$\mathrm{Z}$ zasady dla chorych przeznaczone było oddzielne pomieszczenie. Była to specjalna izba lub cela przeznaczona wyłącznie dla chorych (Pachomiusz, Cezary z Arles, Izydor z Sewilli, Benedykt). W niektórych przypadkach chorzy mieli przeznaczoną tylko dla nich jadalnię, spiżarnię lub kuchnię (Pachomiusz, Cezary z Arles).

Wszystkie reguły przewidują także złagodzenie specjalnie dla chorych wymogów dotyczących spożywania posiłków, postów, a także korzystania z kąpieli. Augustyn i Izydor podkreślają, że chorzy mogą spożywać posiłki poza wyznaczonym czasem. Izydor mówi także o konieczności podawania chorym delikatniejszych posiłków, nie podaje jednak bliższych szczegółów co do jadłospisu chorych. Niektóre reguły wskazują na pokarmy, które mogli spożywać chorzy, a nie mogli ich spożywać pozostali mnisi bądź dziewice. Pachomiusz przewiduje specjalnie dla chorych wino i zupę. Cezary z Arles zwalnia dziewice od postu i pozwala im spożywać wino i mięso. Także Benedykt pozwala spożywać chorym braciom mięso, natomiast Leander wręcz zaleca chorym siostrom picie wina.

We wszystkich klasztorach istniały przepisy dotyczące przynajmniej bardzo powściągliwego korzystania z kąpieli, jeśli w ogóle nie była ona zakazana zdrowym mnichom i mniszkom. Wyjątek i w tym przypadku czyniono dla chorych. Tylko im było wolno korzystać

\footnotetext{
69 Ibidem, 36, s. 152: „Sed et ipsi infirmi considerent in honorem Dei sibi servire et non superfluitate sua contristent fratres suos servientes sibi. Qui tamen patienter portandi sunt, quia de talibus copiosior mercis adquiritur".

70 Por. ibidem, 36, s. 154-155.

71 Ibidem, 36, s. 154-155: [...] ,quotiens expedit [...]”.

72 Por. ibidem, 36, s. 154-155.

73 Por. ibidem, 39, s. 162-163.

74 Por. ibidem, 41, s. 166-167.
} 
z kąpieli dla zdrowia. Prawodawcy zakonni w tym przypadku uważali kąpiel za konieczność, zwłaszcza jeśli chorym zalecał nią lekarz.

Chorych także zwalniano z obowiązku pracy, zwłaszcza ciężkiej. Jak wskazują na to przynajmniej reguły Augustyna i Izydora, mogło się zdarzać, że niektórzy mnisi symulowali chorobę, by w ten sposób unikać pracy. Stąd często nie zwalniano chorych z wszelkich prac. Stąd, jak sugeruje to zwłaszcza św. Benedykt, mieszkańcy klasztorów powinni wykonywać przynajmniej jakieś lżejsze zajęcia, by nie zagrażała im bezczynność.

Należy zdawać sobie sprawę z tego, że reguły monastyczne nie ukazują całej rzeczywistości na temat chorych mnichów bądź dziewic w klasztorach. Ze względu na swój normatywny charakter reguły ustanawiają zasady tylko w najważniejszych kwestiach dotyczących życia chorych w poszczególnych wspólnotach monastycznych. Stąd milczą one na temat bardzo wielu spraw związanych z problemem choroby i zdrowia w klasztorach. Niewiele wiemy choćby na temat, jak wyglądała opieka lekarska w klasztorach. Sporadycznie tylko niektóre reguły wspominają o lekarzach, którzy zalecają chorym kąpiel. Nie znajdziemy w regułach nic więcej na ich temat. Czy klasztory miały swoich lekarzy, czy mieszkańców klasztorów leczyli medycy z zewnątrz? Jakie przepisywali chorym lekarstwa? Czy wykonywano jakieś inne zabiegi względem chorych? Na jakie choroby najczęściej chorowano? Czy można mówić o profilaktyce zdrowotnej? To tylko niektóre z pytań, na które w ogóle nie można udzielić odpowiedzi w świetle reguł monastycznych.

\section{The care of the sick in ancient monastic life in the light of the selected monastic rules Summary}

The purpose of the article is the attempt to answer the question of how Eastern and Western monastic rules normalized the life of those who were ill in ancient monasteries. Did they have among their brothers or sisters some special status? Who were responsible for the sick in the monastery and how hey were responsible for the care of the ill? In this regard, monastic rules are an interesting and unique source of information about activities undertaken to care for ill members of the monastic community. In this regard 7 monastic rules were identified and analyzed. These rules were written in different regions of the contemporary world: Egypt, North Africa, Gaul, Italy and Spain. One was written during IV and VII of century and they concern monks and consecrated women. Each rule deals with the care of the sick those from among the brothers or sisters with a designated role in caring for the sick. These were usually nurses and cellarers. Some rules determined personality traits required. The general supervision over the care of the sick was entrusted to superior of the monastery. Separate rooms or the cells were identified for the sick, sometimes the dining room, the storeroom or the kitchen. All rules seek to ease for the ill requirements concerning of the consumption of meals, fasts, and hygiene needs. They should, if able, perform lighter duties

Keywords: the monasticism, monasteries, monastic rules, ill, the illness

Nota o Autorze: Ks. dr hab. Tadeusz Kołosowski jest pracownikiem naukowo-dydaktycznym Instytutu Nauk Historycznych Uniwersytetu Kardynała Stefana Wyszyńskiego, profesorem nadzwyczajnym w Katedrze Historii Starożytnej. Jego zainteresowania naukowo-badawcze koncentrują się wokół dziejów wczesnego chrześcijaństwa i literatury wczesnochrześcijańskiej. 